Banwell, J. G., Hutt, M. S. R., and Tunnicliffe, R. (1964). East African Medical fournal, 41, 46

Banwell, J. G., Marsden, P. D., Blackman, V., Leonard, P. T., and Hutt, M. S. R. (1967). American Fournal of Tropical Medicine and Hygiene, 16,304 .

Burman, D. (1965). Archives of Diseases in Childhood, 40, 526.

Butterworth, C. E., and Perez-Santiago, E. (1958). Annals of Internal Medicine, 48, 8

Chacko, C. J. G., Job, C. K., Johnson, S., and Baker, S. J. (1961). Indian Fournal of Pathology and Bacteriology 4, 203.

Colwell, E. J., Welsh, J. D., Legters, L. J., and Proctor, R. F. (1968). fournal of the American Medical Association, 206, 2273.

Druskin, M. S., Wallen, M. H., and Bondgura, L. (1962). New England Fournal of Medicine, 267, 483.

Dyer, N. H., and Dawson, A. M. (1968). British Medical fournal, 2, 161, 225

England, W. N. J., and O'Brien, W. (1966). Gut, 7, 120.

Falaiye, J. M. (1969). West African Medical fournal, 18, 71

Falaiye, J. M. (1970). Journal of Tropical Medicine and Hygiene, 73, 119

Garcia, S. (1968). American Fournal of Clinical Nutrition, 21, 1066.

Gilles, H. M., Watson-Williams, E. J., and Ball, P. A. J. (1964). Quarterly Fournal of Medicine, 33, 1

Ingelfinger, F. J., et al. (1967). Federation Proceedings, 26, 1388.

Jeejebhoy, K. N., Desai, H. G., Moronha, J. M., Antia, F. P., and Parekh, D. V. (1966). Gastroenterology, 51, 333.

Klipstein, F A (1964) Gastroenterology, 47, 457

Klipstein, F. A., and Falaiye, J. M. (1969). Medicine, 48, 475.
Klipstein, F. A., Samloff, I. M., and Schenk, E. A. (1966). Annals of Internal Mecicine, 64, 575.

Leblond, C. P., and Messner, B. (1958). Anatomical Record, 132, 247.

Leblond, C. P., and Walker, B. E. (1956). Physiological Reviews, 36, 255

Lindenbaum, J. (1965). British Medical fournal, 2, 326.

Lindenbaum, J. (1968). American fournal of Clinical Nutrition, 21, 1023. Lindenba:1m, J., Jamiul Alam, A. K. M., and Kent, T. H. (1966a). British Medical fournal, 2, 1616.

Lindenbaum, J., Kent, T. H., and Sprinz, H. (1966b). Annals of Internal Medicine, 65,1201

Milner, P. F., Irvine, R. A., Barton, C. J., Bros, G., and Richards, R (1965). Gut, 6, 574.

Russel, P. K., Aziz, M. A., Ahmad, N., Kent, T. H., and Gangarosa, E. J. (1966). American fournal of Digestive Diseases, 11, 296.

Sheehy, T. W., Legters, J. J., and Wallace, D. K. (1968). American fournal of Clinical Nutrition, 21, 1013.

Sheehy, T. W., Rubini, M. E., Perez-Santiago, E., Santini, R., and Haddock, J. (1961). Blood, 18, 623 .

Sprinz, H., et al. (1962). American fournal of Clinical Pathology, 38, 43. Stanfield, J. P., Hutt, M. S. R., and Tunnecliffe, R. (1965). Lancet, 2 519.

Tandon, B. N., Das, B. C., Saraya, A. K., and Deo, M. G. (1966). British Medical fournal, 1, 714 .

Tandon, B. N., Das, B. C., Saraya, A. K., Ramachandran, K., and Sama, S. K. (1969). Gut, 10, 360.

Watson, W. C., Paton, E., and Murray, D. (1965). Lancet, 2, 47

Zalusky, R., and Herbert, V. (1961). New England fournal of Medicine, 365, 1033.

\title{
Fibrin Degradation Products and Ovarian Tumours
}

\author{
B. ÅSTEDT, L. SVANBERG， I. M. NILSSON
}

British Medical fournal, 1971, 4, 458-459

\section{Summary}

Fibrin degradation products (F.D.P.) were determined in the serum of 163 women in whom ovarian tumours had been suspected on palpation at gynaecological examination and who were afterwards examined by laparoscopy or subjected to laparotomy. F.D.P. were found in the serum $(0.5-30 \mathrm{mg} / 100 \mathrm{ml})$ of $23(72 \%)$ out of 32 patients with malignant tumours. Of 131 patients with benign findings F.D.P. (traces to $2 \mathrm{mg} / 100 \mathrm{ml}$ ) were found in six $(4.5 \%)$, and in most of these the occurrence of F.D.P. could be explained on other clinical grounds. The findings suggest that the examination of F.D.P. in suspected malignant ovarian tumour may be of diagnostic value.

Determination of F.D.P. in malignant ascitic fluid showed very high values, ranging between 40 and $350 \mathrm{mg}$ / $100 \mathrm{ml}$. This argues for the occurrence of F.D.P. in the blood being due to an extravascular breakdown of fibrin caused by tumour cells, but they may also be due to thromboplastic and fibrinolytic agents from the tumour entering the blood stream.

\section{Introduction}

Malignant tumours have coagulative properties (O'Meara, 1958) and their vascularization and growth require a fibrin network as a matrix (see Laki and Yancey, 1968). A neoplasm may also possess fibrinolytic activity (Cliffton and Grossi, 1955; Thornes, 1967; Peterson et al., 1968; Davidson et al., 1969; Böck et al., 1970). The activity of such coagulative and fibrinolytic processes during tumour growth may be reflected by fibrin degradation products (F.D.P.) in the blood. Merskey et al. (1966) and

Allmănna Sjukhuset, Malmø, Sweden

B. ASTEDT, M.D., Senior Gynaecologist

L. SVANBERG, M.D., Senior Gynaecologist

I. M. NILSSON, M.D., Professor of Medicine
Colman et al. (1970) reported the occurrence of F.D.P. in the serum of some patients with malignant diseases. Hedner and Nilsson (1971) found F.D.P. in the serum of $61 \%$ of 162 patients with malignant tumours.

The purpose of the present investigation was to find out whether the finding of F.D.P. might be of diagnostic value in patients with clinically suspect ovarian tumour.

\section{Patients and Methods}

The clinical material consisted of 163 women in whom palpation at gynaecological examination gave reason to suspect ovarian tumours. Blood samples were obtained for determination of F.D.P. The patients were afterwards examined by laparoscopy or subjected to laparotomy. Biopsy specimens and operative specimens were afterwards examined histologically and classified. Also ascitic fluid, when found, was examined for F.D.P.

Collection of Blood.-Blood was collected in tubes containing an inhibitor of fibrinolysis, aminocaproic acid, to avoid in-vitro fibrinolysis, as well as thrombin to prevent incomplete coagulation with residual fibrinogen. Serum from these samples was prepared in the way described by Niléhn (1967).

Determination of F.D.P.-F.D.P. were determined by the immunochemical method of Niléhn (1967). In this method an antiserum against the D-fraction of the F.D.P. is applied to agarose gel. With high-voltage electrophoresis serum (diluted $1 / 5$ ) migrates into the gel. If F.D.P. (X, Y, or D products) are present, they will produce precipitation peaks. The height of such peaks is measured and related to a standard of substances of high molecular weight. In the presence of aminocaproic acid and thrombin this method will not show any F.D.P. in the serum of healthy control women, even in repeated assays.

\section{Results}

Of the 163 women examined 32 were found to have malignant tumours. In the remaining 131 the lesions were benign. Of the 
32 patients with malignant tumours F.D.P. were found in the serum of $23(72 \%)$ in amounts above $0.5 \mathrm{mg} / 100 \mathrm{ml}$. Of these 23 the F.D.P. level $(\mathrm{mg} / 100 \mathrm{ml})$ was $0.5-1.0$ in $2,1.5-5$ in 16 , 6-10 in 3, and $11-30$ in 2. F.D.P. were found in high concentrations $(40-350 \mathrm{mg} / 100 \mathrm{ml})$ in the ascitic fluid of five malignant cases. Of the 131 patients with benign lesions F.D.P. were found in $6(4.5 \%)$ in amounts ranging from traces to $2 \mathrm{mg} / 100$ ml. No correlation was found between F.D.P. and the E.S.R.

The malignant cases are summarized in Table I. The commonest tumour associated with F.D.P. was serous cystadenocarcinoma. Three cases of cystadenocarcinoma had no demonstrable F.D.P. However, these tumours were well defined and showed no gross or microscopical signs of having spread beyond the capsule.

TABLE I-F.D.P. in Patients with Malignant Tumours

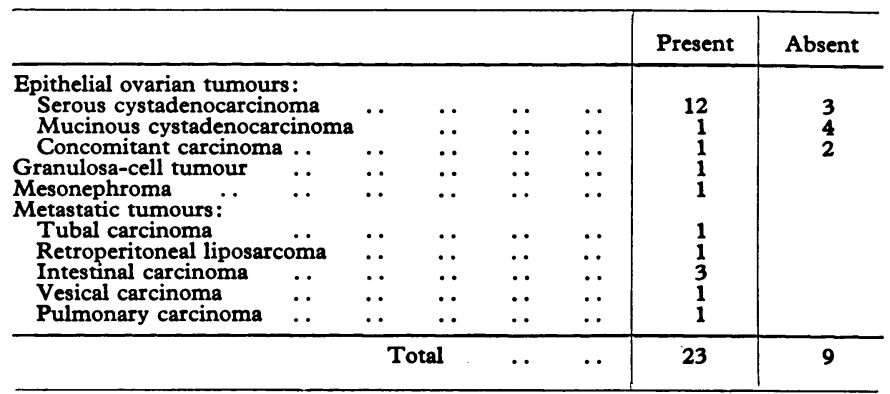

Only six patients with benign conditions had demonstrable F.D.P. (Table II). Of these, one patient with endometriosis showed signs of bleeding and another had a myoma with degenerative changes.

TABLE II-F.D.P. in Patients with Non-malignant Conditions

\begin{tabular}{|c|c|c|c|c|c|}
\hline & & & & Present & Absent \\
\hline 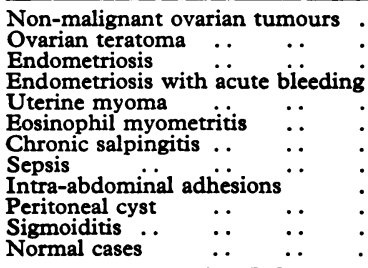 & 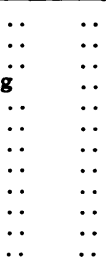 & $\begin{array}{l}\because \\
\because \\
\because \\
\because \\
\because \\
\because \\
\because \\
\cdots\end{array}$ & $\begin{array}{l}\ldots \\
\because \\
\ldots \\
\cdots \\
\cdots \\
\cdots \\
\therefore \\
\therefore\end{array}$ & $\begin{array}{l}1 \\
1 \\
2 \\
1\end{array}$ & $\begin{array}{r}64 \\
8\end{array}$ \\
\hline \multicolumn{2}{|r|}{ Total } & $\cdots$ & .. & 6 & 125 \\
\hline
\end{tabular}

\section{Discussion}

O'Meara (1958) showed that malignant tissues and cells possess coagulative properties. He also found a clot-forming enzyme in such tumours. Experiments by Laki and Yancey (1968) suggested that the clotting enzyme in tumour extracts was thrombin. These authors believe that a fibrin network is necessary for the vascularization and growth of tumours.

Cliffton and Grossi (1955) found fibrinolytic activity in a large number of human tumours tested on fibrin plates. Peterson et al. (1968) found fibrinolytic activity in experimental tumours by a histochemical method. Davidson et al. (1969) showed a giant-cell carcinoma of the lung to be rich in plasminogen activator.
F.D.P. occur in the blood in conditions where there is general fibrinolysis, intravascular coagulation with secondary fibrinolysis, or local deposition of fibrin with secondary fibrinolysis. The coagulative properties and the fibrinolytic activity in tumour tissues may lead to the development of such conditions. It is not improbable that the F.D.P. also result from breakdown of fibrin or fibrinogen by proteolytic enzymes other than plasmin and occurring in the malignant cells.

The largest group of malignant tumours in patients with demonstrable F.D.P. consisted of serous cystadenocarcinoma (Table I). These tumours have a high content of plasma proteins (Kjellgren, 1967). The serous cystadenocarcinomas which were not associated with demonstrable F.D.P. were all well defined and showed no gross or microscopical signs of penetration of the capsule.

F.D.P. were also found in some of the patients with benign changes (Table II). In the patient with endometriosis there were, however, fresh bleedings which might explain the occurrence of F.D.P. In eosinophilic myometritis there is often concealed allergy. Robbins and Stetson (1959) believed that all antigen-antibody reactions can cause an intravascular deposition of fibrin. In one case there was sepsis, a condition in which F.D.P. are nearly always found (Hedner and Nilsson, 1971). In the woman with myoma there were degenerative changes with fibrin deposits.

Of the patients with malignant tumours, then, F.D.P. were found in $72 \%$. In those with benign changes F.D.P. were found in $4.5 \%$, and in most of these the occurrence of F.D.P. could be explained on some other clinical ground. This suggests that examination for F.D.P. in patients with suspected malignant ovarian tumours may be of diagnostic value. Absence of demonstrable F.D.P. does not exclude malignancy. The occurrence of F.D.P. does, however, lend support to a provisional diagnosis of malignant disease and indicates further investigation.

It is debatable whether the occurrence of F.D.P. is due to extravascular breakdown of fibrin by tumour cells-a possibility suggested by the high values found in the ascitic fluid-and/or to thromboplastic and fibrinolytic agents from the tumour entering the blood stream.

The investigation was supported by grants from the Swedish Medical Research Council (B71-19X-87-07A) and from the Medical Faculty, University of Lund.

\section{References}

Böck, F., Kraus, H., Blümel, G., and Koos, W. (1970). Neuro-chirurgie' $16,542$.

Cliffton, E. E., and Grossi, C. E. (1955). Cancer, 8, 1146.

Colman, R. W., Meyers, A. R., Bloch, K. J., Niewiarowski, S., and Thomas, D. P. (1970). Proceeding of the 13th Congress of the International Congress of Haematology, p. 253. Munich.

Davidson, J. F., McNicol, G. P., Frank, G. L., Anderson, T. J., and Douglas, A. S. (1969). British Medical fournal, 1,88.

Hedner, U., and Nilsson, I. M. (1971). Acta medica Scandinavica, 189, In press.

Kjellgren, O. (1967). Gynekologisk Cancer. Stockholm, Almqvist and Wiksell. Laki, K., and Yancey, S. T. (1968). Fibrinogen, ed. K. Laki, p. 359. New York, Marcel Dekker.

Merskey, C., Kleiner, G. J., and Johnson, A. J. (1966). Blood, 28, 1.

Niléhn, J.-E. (1967). Thrombosis et diathesis haemorrhagica, 18, 89.

O'Meara, R. A. O. (1958). Irish fournal of Medical Science, p. 474.

Peterson, H.-I., Peterson, A., and Rudenstam, C.-M. (1968). Acta chirurgica Scandinavica, Suppl. No. 394.

Robbins, J., and Stetson, Ch. A. (1959). Federation Proceedings, 18, 594.

Thornes, R. D. (1967). Endogenous Factors Influencing Host-Tumor Balance, ed. R. W. Wissler, T. L. Dao, and S. Wood jun., p. 255. Chicago, University of Chicago Press. 